an inspiring address on the proper functions of such an institution. This has just been published in pamphlet form with the title "The Proper Function and Scope of a National Art Gallery and Museum". "A public museum . . . should not be a mausoleum of dead specimens, the resort only of monastic specialists or interested collectors, but a vitalising power-house radiating currents of intellectual energy and calling forth latent genius in all classes of the community". The difficulty is to know how best to do it. Lord Bledisloe suggests many possibilities : popular exhibits, the encouragement of school children, travelling collections to country districts, special exhibits relating to sanitation, hygiene, child-welfare or town-planning, a comprehensive department illustrative of British seafaring life from the earliest times, and so on. $\mathrm{He}$ summarises with insight the values of an orderly ethnographic collection-the scientific study of early civilisations, the promotion of a more sympathetic understanding of subject races, the provision of useful equipment to prospective Colonial administrators and pioneers, and the stimulation of trade by suggesting new ideas both to importers and exporters. On the museum side and on the art gallery side he warns curators and administrators over and over again against the danger of accepting gifts too readily, and of accepting gifts with conditions. He sees in the foundation of the new institute a landmark in the definite and vigorous intellectual and spiritual progress of all classes and both races of people in the Dominion.

WhILE in New Zealand Lord Bledisloe was laying emphasis upon the educative aspects of museums, at the Toronto Meeting of the American Association of Museums, on May 31, Prof. John R. Dymond, director of the Royal Ontario Museum of Zoology, sounded a warning note about the danger of too much educational policy (Science Service, Washington, D.C.). Education is one of the important functions of a museum, but it is not the only one, or the primary one. The peculiar work for which museums exist is to collect and preserve the irreplaceable materials needed for the advancement of knowledge. Should too great a proportion of time or energy or income be spent on educational activities, the real work of the museum will suffer. There are other agencies in every State devoted to educational work, but there is nothing to replace the museum if it halts in its labour of making and conserving collections. But the problem is not quite so simple as it looks-there are things that are not worth the labour and expense of collecting and preserving, and who is to draw the line between judicious collecting and aimless, useless amassing ? Perhaps the educational aspect is one of the soundest criteria.

\section{The Psychic Thumb Print Controversy}

IN Bulletin 22 of the Boston Society for Psychic Research, published in April 1934, is printed the reply to Mr. Thorogood's lengthy report on the alleged psychic thumb prints produced by the American medium 'Margery', which document was issued as vol. 22 of the Proceedings of the American Society for Psychical Research and which was reviewed in NATURE of April 14, p. 550. The controversy revolves around the report of the discovery that both the right and left thumb prints of 'Walter' (the medium's control) are in reality identical with those of her dentist now living in Boston. These charges were examined by the officials of the American Society for Psychical Research, who came to the conclusion that they were without foundation, although it was admitted that in the case of one of the thumb prints the resemblance was close. Counter charges of bad faith, falsification of material evidence and sinister motives were made, and it was alleged that certain of the wax prints obtained exhibit clear signs of alteration. In the present Bulletin these statements are considered, and further counter charges are made against the officers of the American Society for Psychical Research, including the suggestion that counterfeit waxes have been introduced and dates forged. In a well-balanced review of Mr. Thorogood's book, Dr. Harold Cummins examines the theory that the sets of prints are not identical, but finds himself unable to accept the claim. Moreover, he severely criticises certain photomicrographs printed by $\mathbf{M r}$. Thorogood inasmuch as in his opinion they are not strictly comparable.

\section{New 24-Cylinder Aero Engine}

As air-cooled 24-cylinder aero engine, the NapierDagger, has just completed its 100-hour Air Ministry type test. It has already been flown for more than sixty hours in a Hawker Hart day bomber aeroplane, and took part in this year's R.A.F. display on June 30 . The 24 cylinders are arranged in four blocks of six. Two blocks are set above and two below the crankcase, giving the engine the form of a letter $\mathrm{H}$ viewed from the front. This arrangement makes for compactness, especially in frontal area, which is about equal to that of a modern water-cooled engine of similar output. Thus the air-cooled engine gains to the extent of the head resistance of the radiators or such devices as are necessary for cooling the liquid in the other. Each pair of upper and lower cylinder blocks has a separate crank-shaft which transmits the power through gearing to the airscrew shaft. The reduction in this gearing allows the very high engine speed of 4,000 revolutions per minute, while the airscrew travels at such lower speeds as its efficiency demands. One of the most interesting features in the engine is the use of hydraulic impulses to operate the valve gear. This removes the need of rocker arms and also gives a quieter engine. The engine is supercharged to develop its maximum power of $705 \mathrm{~h} . \mathrm{p}$. at a height of $12,000 \mathrm{ft}$., and, at a cruising rate of 3,500 revolutions a minute, it yields 630 h.p. These are with standard fuels; much bigger outputs with 'doped' fuel and higher compression ratios are anticipated. A smaller version of this engine has been flying for some time. This has only 16 cylinders arranged in banks of four. It was known originally as the $H$ engine and is now named the Rapier. The bigger engine makes the type fit for use in military aircraft. 